\title{
Mitosis-targeted anti-cancer therapies: where they stand
}

\author{
K-S Chan ${ }^{1}$, C-G Koh ${ }^{*, 1}$ and H-Y Li,
}

The strategy of clinically targeting cancerous cells at their most vulnerable state during mitosis has instigated numerous studies into the mitotic cell death (MCD) pathway. As the hallmark of cancer revolves around cell-cycle deregulation, it is not surprising that antimitotic therapies are effective against the abnormal proliferation of transformed cells. Moreover, these antimitotic drugs are also highly selective and sensitive. Despite the robust rate of discovery and the development of mitosis-selective inhibitors, the unpredictable complexities of the human body's response to these drugs still herald the biggest challenge towards clinical success. Undoubtedly, the need to bridge the gap between promising preclinical trials and effective translational bedside treatment prompts further investigations towards mapping out the mechanistic pathways of MCD, understanding how these drugs work as medicine in the body and more comprehensive target validations. In this review, current antimitotic agents are summarized with particular emphasis on the evaluation of their clinical efficacy as well as their limitations. In addition, we discuss the basis behind the lack of activity of these inhibitors in human trials and the potential and future directions of mitotic anticancer strategies.

Cell Death and Disease (2012) 3, e411; doi:10.1038/cddis.2012.148; published online 18 October 2012

Subject Category: Cancer

Facts

1. The fragility of cancer cells when they undergo division serves as a critical intervention point in chemotherapy.

2. This strategy encompasses a prolonged arrest of cells in mitosis, culminating in mitotic cell death (MCD).

3. Classical antimitotic therapies achieved some level of success, but complete neoplasm eradication is rare and often plagued with issues of slippages, resistance and toxicity.

4. The majority of newer mitosis-targeting drugs currently under development could not translate their preclinical efficacy to clinical response in human trials.

\section{Open Questions}

1. Are antimitotics still relevant as a potent chemotherapeutic strategy?

2. How to improve the selectivity of antimitotics towards cancer cells without off-site(s) targeting?

3. Can the balance of therapeutic benefits and reversible side effects be struck in combinatorial treatments consisting of multiple antimitotics targeting different stages of mitosis?

4. What about multi-phasic combinatorial therapies encompassing antimitotics, DNA-damaging agents (including antimetabolites and antibiotics) and/or antiangiogenic drugs?

Mitosis is an elaborate process in actively proliferating cells, resulting in the division of duplicated sets of chromosomes and two genetically identical daughter cells. Failure of cellcycle checkpoint regulations often results in aneuploidy and genetic instability, culminating either in cell death or in cancer. ${ }^{1}$ In the same vein, cancer describes abnormal, deregulated cells that undergo unrestricted divisions.

Despite being the shortest phase of the cell-cycle, mitosis orchestrates major changes in multiple cellular components. Signaling pathways are intricately activated and silenced on cues, and timely prompting of protein degradation processes leads to gross dynamic reorganization of the cell structure. Hence, it is considered to be the most fragile period of the cellcycle, during which it is highly susceptible to cell death when exposed to various insults. ${ }^{2}$ Damages incurred by these cellular stressors activate the spindle assembly checkpoint (SAC), which halts progression and induces a prolonged mitotic arrest. Such delays are likely to signal the induction of a death program, known as mitotic cell death (MCD), and it is widely exploited as an antiproliferative strategy for the development of chemotherapeutic agents. Induced MCD often centralizes around the inhibitions of mitotic progressions achieved through spindle-disruption activities and the

\footnotetext{
${ }^{1}$ Division of Molecular and Cell Biology, School of Biological Sciences, College of Science, Nanyang Technological University, Singapore, Singapore ${ }^{*}$ Corresponding author: H-Y Li or C-G Koh, Division of Molecular and Cell Biology, School of Biological Sciences, Nanyang Technological University, Singapore 637551, Singapore. Tel: +65 6316 2931; Fax: +65 6791 3856; E-mail: hyli@ntu.edu.sg or cgkoh@ntu.edu.sg

Keywords: cancer; antimitotic; chemotherapy; tumor growth; mitotic slippage

Abbreviations: CIN, chromosomal instability; CPC, chromosome passenger complex; MCD, mitotic cell death; MTA, microtubule-target agent; PIk, polo-like kinase; SAC, spindle assembly checkpoint; UPS, ubiquitin-proteasome system.

Received 31.7.12; revised 12.9.12; accepted 12.9.12; Edited by H-U Simon
} 
restriction of key mitotic regulatory proteins in terms of availability and functionality.

Given the lack of an accurate and consistent definition of $M C D$, as long as cell death processes are activated within the duration of mitosis leading up to cell death thereafter, they are regarded as MCD. There are crosstalks between different modes of cell death. Thus far, antimitotics-induced MCD exhibits features that resemble the apoptotic pathway (caspase activation, cytochrome $c$ release and chromosome condensation), ${ }^{3}$ necrosis-like phenotype (caspase-independent death), ${ }^{4}$ and autophagy characteristics. ${ }^{5}$ It is likely that molecular events that drive cell death are shared across different pathways through simultaneous activations or sequential triggering in a dying cell.

Regardless of the targets and mechanisms, antimitotics interfere with normal mitotic propagation without seriously affecting quiescent, non-dividing cells. Spurred by the success of paclitaxel and vinblastine for the treatment of various malignancies, $\mathrm{MCD}$ is considered to be highly effective in treating tumor cells. ${ }^{6}$ Nevertheless, from the perspective of antimitotic therapy, relapses are not uncommon and total eradication of clinical tumors is rare. Even with a new generation of promising antimitotics aiming at novel targets, especially the mitotic kinases and spindle motor proteins, clinical trial results are disappointing. In this review, we will focus on the existing chemomitotic approaches, evaluate the efficacy behind mitosis-based therapies and discuss possible directions for novel therapies.

\section{Mitosis-Selective Strategies Against Cancer}

Anti-microtubular drugs. With a long history of clinical efficacy, microtubule-targeting agents (MTAs) remain to date the most classical yet, reliable antimitotics. This class of drugs disrupts proper microtubule dynamics, leading to abnormal spindle formation, chromosome misalignment and the perpetual activation of SAC. ${ }^{7}$ MTAs can be further subcategorized into (i) microtubule-destabilizing agents, like Vinca alkaloids, that prevent microtubule polymerization and (ii) microtubule-stabilizing agents, like taxanes and Epothilones, that stimulate polymerization. ${ }^{8}$ MTAs have shown antitumor activity in a wide range of tumors, particularly breast, ovarian, non-small-cell-lung and head-and-neck cancers. ${ }^{9}$ The microtubule stabilizers typified by Taxol bind $\beta$-tubulin with high affinity along the interior surface of the microtubules, thereby inducing conformational change in the tubulin, which increases and stabilizes its interaction with neighboring tubulin molecules. ${ }^{8}$ Although mitotic chromosomes are still able to attach to Taxol-stabilized microtubules, tension is compromised across sister chromatids and proper chromosome biorientation is not achieved. ${ }^{10}$

On the other hand, vinblastine typifies the microtubule destabilizers. It is often used in combination with other chemotherapeutic drugs for treatment of cancers such as lymphoma, leukemia, testicular and breast cancer. Vinblastine causes microtubule depolymerization and targets both tubulin monomers and microtubules by binding to $\beta$-tubulin at a region adjacent to the GTP binding site known as the vinca domain. The subsequent conformational change in tubulin then promotes self-association and prevents microtubule formation. ${ }^{8}$ The mode of action may be different from the microtubule stabilizers, but it is the SAC-dependent mitotic delay that enhances cell vulnerabilities towards MCD or, alternatively, death after mitotic slippage.

Although MTAs are developed to selectively target actively dividing cells by virtue of the intense turnover and restructuring of spindles during mitosis, interphase cells may be targeted too, as microtubules are prevalent throughout the cell-cycle. Hence, undesirable effects to non-proliferating cells are observed through disrupted physiological processes such as vesicular trafficking, axonal transport and maintenance of cytoskeleton functions. ${ }^{11}$ Myeloid toxicity and neurotoxicity are common, resulting from mitotic arrestrelated impairment in cycling bone marrow cells and functional disruption in neuronal cells. In addition, MTA resistance further compounds the challenges. ${ }^{8}$ Therefore, there is a strong interest in developing novel drugs that do not affect microtubule structures and yet are able to specifically inhibit the progression of mitosis.

\section{Anti-kinases}

Entry kinases. One class of new targets involves kinases responsible for directing cells into mitosis. Generally, mitotic entry is driven by the activation of a 'mitosis-promoting factor', which comprises the cyclin-dependent kinase 1 (Cdk1)/cyclin B1 heterodimer. ${ }^{12}$ The activated Cdk1/cyclin B1 complex kick-starts the mitotic machinery by phosphorylating proteins that are fundamentally involved in chromosome condensation, nuclear envelope breakdown, spindle assembly, centrosome separation and Golgi fragmentation. ${ }^{13}$ Inhibition of Cdk1 blocks mitosis and induces cell death (Table 1). Nevertheless, despite the excitement generated at preclinical stages, human trials on Cdk drugs such as UNC-01 and flavopiridol failed to deliver significant clinical advantages, with majority reports citing toxicity and side effects, thus preventing more rigorous regimen. ${ }^{14}$

Checkpoint kinases 1 and 2 (Chk1 and 2) are DNA damage checkpoint proteins regulating p53 and Cdc25 to mediate cellcycle arrest/apoptosis and Cdk1 activation, respectively. ${ }^{15}$ As G2 checkpoints, they are important for ensuring cells with cellular damage are prevented from progressing into mitosis until the damage is repaired. Studies have shown that the inhibition of checkpoint genes promote DNA damage-induced MCD. ${ }^{16,17}$ Following that, a host of Chk1 inhibitors have been identified and tested for clinical efficacy (Table 1). However, side effects and limited responses plague single-agent therapies using these drugs.

Mitotic kinases. Kinases belonging to the Aurora kinase and polo-like kinase (PIk) families are widely regarded as the bona fide mitotic kinases given their peak expression in mitosis, with little to null detection in G0, G1 and S phases. ${ }^{18}$ The mammalian Aurora members A, B and C are serine/ threonine protein kinases that have multiple essential roles during mitosis. Often times, they are overexpressed in several tumor types, making them ideal targets for cancer therapy. ${ }^{19}$ Several Aurora kinase inhibitors have been established and they are in various stages of clinical development (Table 1). Plks also play critical roles during mitotic progression. Four members of Plks have been 


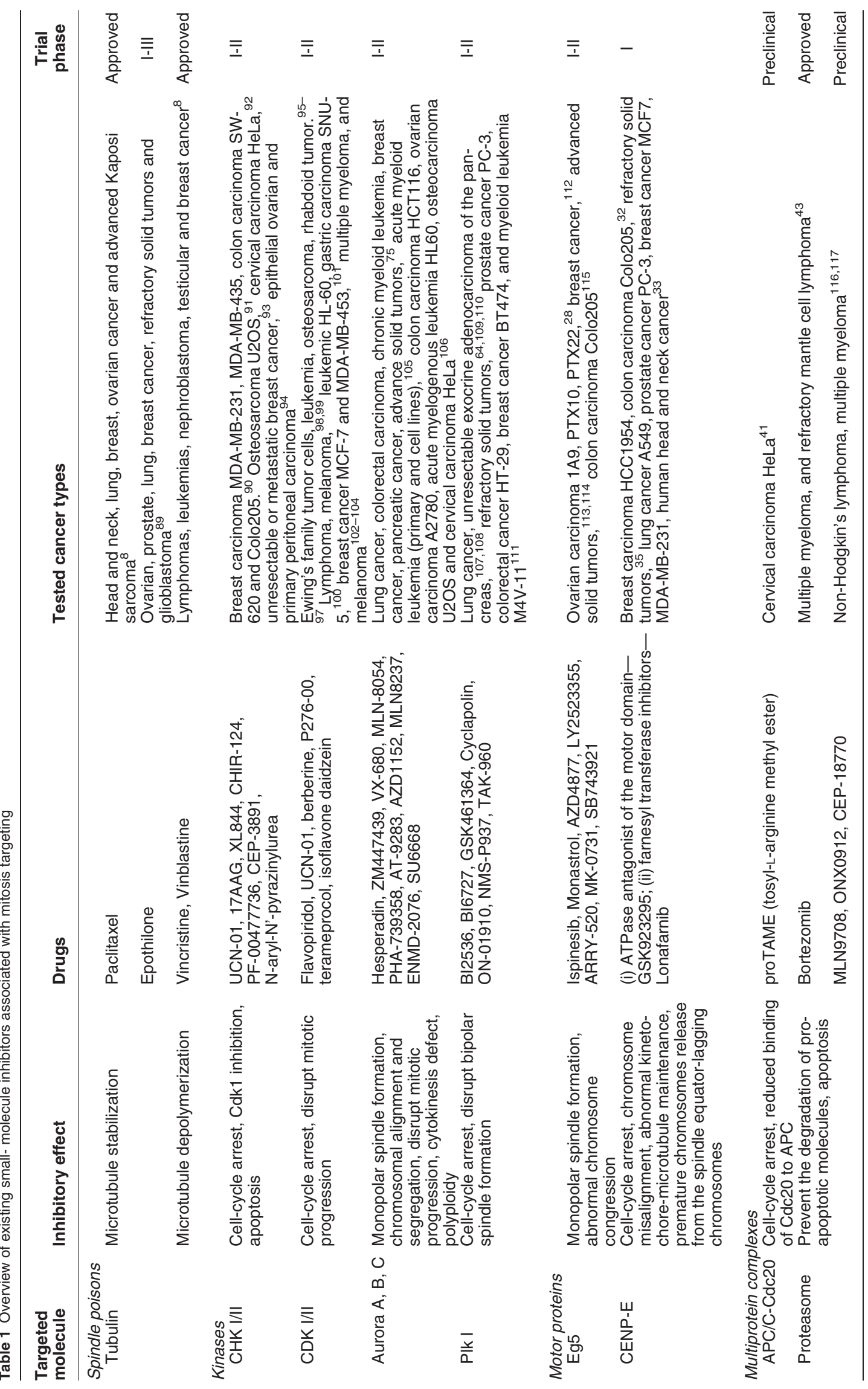


identified in mammalian cells. Plk1 is the most thoroughly studied member. It is involved in spindle assembly, centrosome maturation, SAC activation, chromosome segregation and cytokinesis. In addition, the expression of Plk1 was found to be upregulated in a variety of cancers, including ovarian, bladder, gastric, breast, colon, head and neck, esophageal, thyroid cancers, melanomas and gliomas. ${ }^{20}$ Therefore, targeting Plk1 is viewed as an attractive anticancer strategy.

The spindle pole localization of Plk1 and Aurora A during early mitosis (Figure 1) is functionally coupled to direct centrosome maturation and separation. Targeted inhibition of Aurora A or Plk1 gives rise to SAC activation, mitotic arrest, and increased cell death due to monopolar spindle formation. ${ }^{21,22}$ Tumor-specific partial responses have also been reported in clinical trials utilizing drugs directing at these kinases. ${ }^{23}$ Aurora B inhibitors, however, work differently at the end of mitosis by disrupting cytokinesis and causing polyploidy cells with restricted viability. ${ }^{24}$ Aurora B localizes to the kinetochore, regulating kinetochore-microtubule attachment during metaphase. ${ }^{25}$ It is likely that Aurora B inhibition could also induce SAC-dependent arrest. However, none of these compounds showed spectacular clinical results, with moderate to severe side effects and partial responses recorded at best.
Anti-motor proteins. Building upon anti-microtubular therapy, new targets and strategies were devised to exploit spindle dynamics and functionalities. With the discovery of Monastrol (Eg5 inhibitor) as a potent mitotic arrest inducer, ${ }^{26}$ mitotic kinesins have become anti-cancer targets. Eg5 is a plus end-directed motor protein responsible for centrosome separation and bipolar spindle formation. Compromising Eg5's activities leads to monopolar spindles, abnormal chromosome congression, SAC-dependent arrest and possibly cell death. ${ }^{27}$ Currently, Eg5 inhibitors such as Ispinesib, AZD-4877 and others have entered clinical development (Table 1). Of interest, Eg5 inhibition has been shown to be effective in targeting Taxol-resistant cancer cells. ${ }^{28}$ Furthermore, Eg5 inhibitors do not display severe cytotoxicities and are generally well tolerated. Yet, to date these agents are generally lacking in activity in clinical trials. ${ }^{29}$

Centromeric protein $\mathrm{E}$ (CENP-E) is another targeted mitotic kinesin, minimally found during $\mathrm{G} 1$ and accumulates during late G2 and M-phases. It is localized at the kinetochores (Figure 1) and is required for proper chromosome congression during metaphase. Moreover, it also stabilizes kinetochoremicrotubule attachments and serves as a sensor of SAC by binding to and regulating the activity of BubR1. ${ }^{30,31}$ Existing CENP-E inhibitors can be subdivided into two categories: (i) ATPase antagonist of the motor domain or (ii) farnesyl

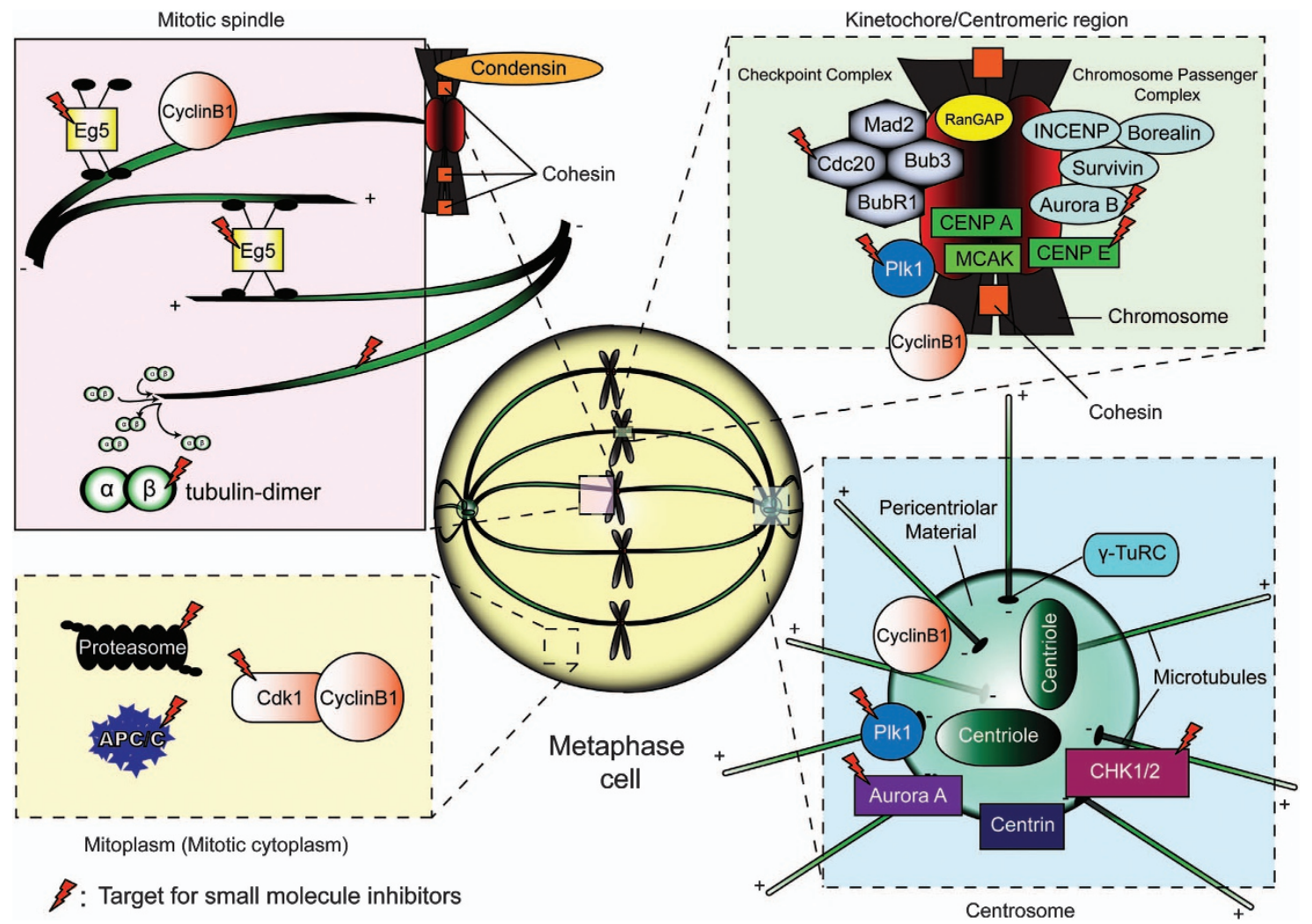

Figure 1 Localization of current druggable protein targets during mitosis (metaphase). The four key subcellular domains highlighted are: (i) mitotic spindle region, (ii) kinetochore/ centromeric region, (iii) centrosomal region and (iv) mitoplasm (nucleoplasm + interphase cytoplasm after the breakdown of the nuclear envelope). It is worth noting that certain proteins exhibit dynamic localization throughout mitosis, such as components of the CPC, which are localized near the centromeres during prophase and metaphase, before shifting to the developing midzone microtubules during anaphase, and finally settled at the midbody during telophase and cytokinesis. Aurora A and PIk1 similarly redistributes to the midbody towards the end stages of mitosis 
transferase inhibitors (FTIs). Hindering the ATPase activity of the CENP-E motor domain stabilizes it with ADP, resulting in CENP-E being tightly bound to the microtubules. This prevents proper chromosome alignment during metaphase, thereby leading to mitotic arrest and MCD. ${ }^{32}$ Conversely, inhibiting the farnesylation of CENP-E perturbs the normal assembly and function of the kinetochore complexes, thereby weakening the kinetochore-microtubule interactions, and activates the SAC. Other observable phenotypes include abnormal chromosomal maintenance, premature release of chromosomes from the spindle equator and lagging chromosomes. ${ }^{33}$ In preclinical work, CENP-E-specific inhibitors have shown positive activity in mouse models and xenograft studies. $^{32,34}$ The first human trial with CENP-E inhibitor GSK923295 showed low levels of myelo/neurotoxicities among patients with refractory solid tumors, warranting further studies to analyze its anti-proliferative capability. ${ }^{35}$

\section{Anti-multiprotein complexes}

$A P C / C-C d c 20$. The anaphase promoting complex/cylosome $(\mathrm{APC} / \mathrm{C})$ is an E3 ubiquitin ligase, and, together with its coactivator Cdc20, forms the APC ${ }^{\text {Cdc20 }}$ complex involved in driving the progression through anaphase and exiting from mitosis. ${ }^{36}$ Tumorigenesis is linked to mutations and expression deregulations of $\mathrm{APC} / \mathrm{C}$ subunits or its regulators, Cdc20 and Cdh1. ${ }^{37}$ Despite this correlation, targeting the mitotic exit as an anticancer strategy via APC Cdc20 stems from a more pressing issue of resistance against current generation of antimitotics due to mitotic slippage. ${ }^{2}$ During mitotic arrest, SAC prevents the activation of APC ${ }^{\mathrm{Cdc} 20}$, thus restricting the ubiquitination and the degradation of Cyclin $\mathrm{B}$. However, the SAC-enforced inhibition on APC/C activation is not absolute. Slippage is proposed to occur when the $A P C^{\mathrm{Cdc}^{20}}$-mediated background degradation of Cyclin B under the setting of an active SAC exceeds a certain threshold before cell death is initiated, subsequently prompting the cell to escape from mitosis. ${ }^{38}$ Indeed, the depletion of Cdc20 has shown promising results in eliciting complete metaphase arrest in cell lines and prominent tumor cell-killing capability in mouse models. ${ }^{39,40}$ Bolstering the therapeutic approach of APC/C-mitotic exit targeting, a prodrug of TAME (tosyl-L-arginine methyl ester) was found to effectively trigger cell death after prolonged mitosis in tumor cells by reducing the binding of Cdc20 to APC. ${ }^{41}$

Proteasome. Another interesting antitumor target, which is associative but yet to be established as a mitosis-selective approach, is the proteasome. As the executor of the supramolecular ubiquitin-proteasome system (UPS), proteasomes degrade misfolded or dysregulated proteins that have been tagged with ubiquitin molecule(s). Aberrations in the UPS are implicated in malignant transformation, ${ }^{42}$ intensifying efforts to exploit UPS as a potential anticancer strategy. Several proteasome inhibitors are currently undergoing clinical trials (Table 1). Of note, bortezomib had already been approved for the treatment of multiple myeloma and refractory mantle cell lymphoma. ${ }^{43}$ Cyclin B is a ubiquitinated substrate of proteasome, degradation of which is required for mitotic exit. Interestingly, bortezomib had been reported to induce mitotic cell death in natural killer lymphoma cells. ${ }^{44}$
Despite proteasome inhibitors' lack of specificity, the side effects of bortezomib are surprisingly limited. This allows for further development, optimization and combinatorial therapies. Treatments incorporating bortezomib and taxanes significantly intensify cell death relative to individual drug effects in cancer cell lines of gastric, head and neck origins. ${ }^{45,46}$ Unfortunately, these results have yet to be reflected in phase $\mathrm{I} / \mathrm{II}$ clinical trials involving cotreatment using bortezomib and paclitaxel. ${ }^{47,48}$

\section{Emerging targets}

Mcl1. Mcl1 is gaining traction as an antimitotic target with increasing evidences associating its degradation in mitosis to the timely induction of cell death. ${ }^{49}$ As a member of the $\mathrm{Bcl}-2$ family of anti-apoptotic proteins, Mcl1 is able to disrupt Bax and Bak's interaction with the mitochondrial membrane, thereby averting apoptosis initiation. The expression of Mcl1 peaks when a cell is arrested in mitosis either normally (possibly to resolve checkpoint errors) or drug-induced. The apoptotic suppression by $\mathrm{Mcl} 1$ is not permanent, as it undergoes a concerted sequence of phosphorylationpolyubiquitination, culminating in $\mathrm{APC}^{\mathrm{Cdc} 20}$ dependent degradation by the proteasome. ${ }^{50}$ Because of this transient protection, arrested cells will escape death if the cyclin B's level drops to the exit threshold before Mcl1 is degraded sufficiently to elicit apoptotic responses. Studies have shown that $\mathrm{Mcl} 1$ is overexpressed in patient-derived tumors. ${ }^{51,52}$ Regulatory proteins such as protein phosphatase PP2A and deubiquitinase USP9X along the Mcl1 axis have been proposed as a possible intervention point, inhibition of which will promote the degradation of $\mathrm{Mcl} 1$ and abolish its cytoprotectivity. ${ }^{53}$ This strategy could probably boost clinical efficacy in combination with other mitosis-specific therapeutics.

Condensin. Current antimitotics do not aim at the death pathway directly. Rather, intracellular stresses induced during mitotic arrest had been proposed to collectively orchestrate the cell's demise. How this is conducted remains poorly understood. In addition, it is also unknown how chromosomal DNA damage ${ }^{54}$ (often observed in cancer cells treated with chemical agents) can occur on a highly condensed chromosomal structure. Recently, we had identified a novel molecular event directly linking the regulation of condensin to mitotic death. ${ }^{55}$ Our model shows that caspase3-mediated depletion of the condensin 1 subunit Cap- $\mathrm{H}$ and the subsequent loss of chromosomal structural integrity is crucial in MCD. Clearly, these early results require validation for their importance in cancer therapy. Still, condensin-based approaches may be an interesting avenue to devise novel anticancer strategies. Although targeting condensin may not be an orthodox approach given that it is not cancer-specific, it is worth noting that the bulk of condensin's activities abound during mitosis. Condensins are required for proper chromosome assembly, contributing towards condensation and metaphase chromosomal architecture and chromosome segregation in vertebrate cells. ${ }^{56}$ Although condensin has also been implicated to regulate higher-order chromosome structure during interphase, studies on condensin perturbation reveal that aberration occurs predominantly during 
chromosomal condensation and mitotic progression. ${ }^{57}$ Hence, targeted inhibition of condensin will generally affect only dividing cells.

\section{Limitations of Existing Antimitotic Approaches}

The general theme afflicting the development of anticancer therapeutics has always been the inability of high-potential drugs to deliver their efficacy in human trials. These drugs are envisioned to recapitulate the success of MTAs by disrupting mitosis to induce prolonged arrest and cell death, without the ill effects of myelosuppression and neurotoxicities. The question remains, why aren't they working like they are supposed to?

The selectivity of antimitotics is modeled and even marketed as targeting rapidly growing cancer cells without adversely affecting normal tissues consisting mostly of quiescent non-cycling cells. This unintentional propaganda has been going on for so long, established as fact, and misled patients, physicians or even researchers alike. The truth of the matter is, both normal and malignant cells follow a concerted and precisely controlled process to progress through cell division in a similar schedule. Komlodi-Pasztor et al also recently highlighted this misconception (that tumor cells divide more frequently and more rapidly) as the downfall for mitotic agents. ${ }^{58}$ Within the treatment duration, mitosis-specific drugs target only the cells in M-phase, leaving the rest of the G1- or S-phase tumor cells refractory to the cytotoxic effect. ${ }^{59}$ Once the drug is cleared, the likelihood of the remaining tumor cells repopulating the cleared fraction cannot be ruled out. In line with the 'fractional kill theory', chemotherapy necessitates multiple cycles of treatment to remove the tumor. However, the tumor-doubling time in patients is found to be unexpectedly long (some over 300 days for solid tumors and over 700 days for hematopoietic malignancies) compared with cell lines (ranging from 0.5 to 5.4 days) or animal models (ranging from 1.3 to 7.3 days) (Table 2). This may be the reason why encouraging preclinical antimitotics failed as they advanced into human testing. To further compound on the low mitotic index observed in human tumors (estimated to be $<1 \%$ ), the proliferation rate is variable in different patients, origins and locations of the tumors. ${ }^{60-62}$ This can also be extrapolated to

Table 2 Categorical analysis of doubling-time estimates in cancers of selected origins ${ }^{\text {ATCC,58,118-138 }}$

\begin{tabular}{|c|c|c|c|c|}
\hline \multirow[b]{2}{*}{ Cancer origin } & \multicolumn{2}{|c|}{ Cell lines } & \multirow{2}{*}{$\begin{array}{c}\text { Preclinical models } \\
\begin{array}{c}\text { Average doubling } \\
\text { time (days) }\end{array}\end{array}$} & \multirow{2}{*}{$\begin{array}{c}\text { Patient record } \\
\begin{array}{c}\text { Average doubling } \\
\text { time (days) }\end{array}\end{array}$} \\
\hline & ID & $\begin{array}{l}\text { Average doubling } \\
\text { time (days) }\end{array}$ & & \\
\hline \multicolumn{5}{|l|}{ Solid tumors } \\
\hline Colon & $\begin{array}{c}\text { SW480 } \\
\text { CaCO-2 } \\
\text { SW620 } \\
\text { Colo205 } \\
\text { HCT-116 }\end{array}$ & $\begin{array}{l}5.4 \\
3.8 \\
3.2 \\
1.0 \\
0.7\end{array}$ & 3.4 & 391 \\
\hline Prostate & $\begin{array}{l}\text { DU145 } \\
\text { PC-3 }\end{array}$ & $\begin{array}{l}1.2 \\
0.8\end{array}$ & 3.4 & 219 \\
\hline Breast & $\begin{array}{c}\text { HCC1954 } \\
\text { MDA-MB-468 } \\
\text { MCF7 } \\
\text { BT474 } \\
\text { MDA-MB-231 }\end{array}$ & $\begin{array}{l}1.3 \\
1.3 \\
1.2 \\
1.2 \\
1.2\end{array}$ & 5.6 & 152 \\
\hline Skin & $\begin{array}{l}\text { MM8.1 } \\
\text { A375 } \\
\text { A375 }\end{array}$ & $\begin{array}{l}0.8 \\
0.5 \\
0.5\end{array}$ & 5.4 & 147 \\
\hline Lung & $\begin{array}{c}\text { SNU-371 } \\
\text { H2126 } \\
\text { SNU-1330 } \\
\text { H1299 } \\
\text { A549 }\end{array}$ & $\begin{array}{l}4.1 \\
1.7 \\
1.6 \\
1.0 \\
0.9\end{array}$ & 4.4 & 114 \\
\hline \multicolumn{5}{|c|}{ Haematopoetic malignancies } \\
\hline $\begin{array}{l}\text { Chronic lymphoblastic } \\
\text { leukemia (CLL) }\end{array}$ & $\begin{array}{c}\text { MEC1 } \\
\text { MEC2 } \\
\text { WSU-CLL }\end{array}$ & $\begin{array}{c}1.6 \\
1.3 \\
0.75\end{array}$ & 7.3 & $781^{a}$ \\
\hline $\begin{array}{l}\text { Acute lymphoblastic } \\
\text { leukemia (ALL) }\end{array}$ & $\begin{array}{c}\text { Jurkat } \\
\text { SK-9 } \\
\text { CCRF-CEM }\end{array}$ & $\begin{array}{l}2.0 \\
2.0 \\
1.0\end{array}$ & 2.7 & 5.7 \\
\hline $\begin{array}{l}\text { Chronic myelogenous } \\
\text { leukemia (CML) }\end{array}$ & $\begin{array}{l}\text { MEG-01 } \\
\text { KU812 } \\
\text { K562 }\end{array}$ & $\begin{array}{l}1.8 \\
1.0 \\
0.5\end{array}$ & $N \cdot A^{b}$ & 8.0 \\
\hline $\begin{array}{l}\text { Acute Myelogenous } \\
\text { Leukemia (AML) }\end{array}$ & $\begin{array}{l}\text { KG-1 } \\
\text { HL-60 }\end{array}$ & $\begin{array}{l}1.9 \\
1.5\end{array}$ & 1.3 & 2.5 \\
\hline
\end{tabular}

aDenotes average lymphocyte doubling times of patients from stages A, B, and C (Binet's clinical stages)

${ }^{b}$ Not applicable (NA): difficulty in the specific isolation of CML stem cells from the normal hematopoietic stem cells in patients complicates the development of reliable CML animal models ${ }^{139}$ 
heterogeneity in responses to chemotherapy, which has been periodically reported in clinical trials or even in approved regimens. It is worth noting that for blood cancers in general, the doubling times are not too far off between in-patient records and the corresponding cell lines. No doubt the rapid doubling time is associated with aggressive cancers and bad prognosis for the patients. Nonetheless, this also partially explains why chemotherapy is generally more effective against before other complications (mutations, resistance etc) set in.

Although it is valid to reason that the current antimitotics are targeting only a limited fraction of cells within a tumor population, it still does not explain how taxanes achieved considerable clinical efficacy by similarly affecting the propagation of mitosis. Several possibilities had been outlined by Mitchison, ${ }^{63}$ which indirectly underscore the inadequacies of existing drugs. Chief among these factors is the drug retention issue, where paclitaxel has been shown to linger in the tumor cells for a week and is thus able to exert its cytotoxicity longer compared with the newer mitosis-selective inhibitors with a median half-life of approximately $13 \mathrm{~h} .{ }^{35,64-66}$ Additionally, it is likely that quiescent cancer cells can be targeted by paclitaxel as well because of the importance of microtubule dynamic trafficking in cells not undergoing mitosis. These raise serious doubts and warrant re-examination of the development of chemical inhibitors and the validity of mitosis-specific drugs in single-agent therapies.

From a different angle, the scourge of chemotherapy has always been the establishment of resistance to clinical agents before total tumor removal. Mutations and the expression of drug efflux pumps are largely seen as the driving force behind the development of drug resistance. ${ }^{67}$ Antimitotics included, paclitaxel resistance has been linked to aberrant expression of specific beta-tubulin isotypes, mutation within the beta-tubulin itself or even the expression of drug efflux pump such as the ABCB1. ${ }^{68}$ Despite the relatively short time of application, drug resistance had also been reported for the newer mitosisselective agents like the Eg5 inhibitor. ${ }^{69}$ These evidences seem to build upon mitotic slippage, widely considered as the biggest shortcoming of existing antimitotics that is anchored on the basis of mitotic arrest followed by cell death. Unfortunately, not all the arrested cells will die; some adopt different cell fates after slippage, such as death in the following G1 phase, or even exist as viable multiploidy cells (re-enter the cell-cycle and become increasingly unstable and potentially malignant). ${ }^{7}$ The resulting chromosomal instability $(\mathrm{CIN})$ is linked to graver consequences such as development of metastatic capability and acquisition of resistance. ${ }^{70,71}$ This illustrates the dreaded scenario where chemotherapy becomes the selection pressure for cancer to become even more malicious. Nonetheless, excessive $\mathrm{CIN}$ could also lead to non-viable progenies and subsequent lethality. ${ }^{72}$ In fact, exploiting extreme CIN as a positive anticancer approach has been proposed by inhibiting Mps1 (mitotic checkpoint kinase) ${ }^{73}$ or the synergistic effect of mitotic checkpoint inhibition coupled to sublethal doses of paclitaxel. ${ }^{74}$ With that in mind, the ideal antimitotic agent should therefore be effective enough to prevent mitotic slippage, or even if slippage occurs, severe CIN that compromises tumor cell viability must be invoked by the single inhibitor or in combination with other drugs.
The challenge of identifying or designing more specific and potent drugs, especially against families of proteins with high sequence similarities, slows the advent of antimitotic approaches. Often times, the current generation of pan/ multi-targeted drugs like Aurora A, Cdk1 or Plk inhibitors show lack of activity, specificity and increased toxicity, especially if the targeted kinase is regulating a plethora of substrates. ${ }^{75}$ In addition, Plk2 and Plk4 have been suggested to act as tumor suppressors. ${ }^{76,77}$ A Plk1 inhibitor, which concurrently recognizes Plk2 and Plk4, may enhance tumorigenesis. It remains a hurdle to discover robust inhibitors against multiprotein complexes such as the mitosis-specific APC/C, SAC or even the proteasome. The obstacles are in expressing such huge recombinant proteins and then isolating them to high levels of purity for screening purposes. Additionally, these proteins have relatively large flat surfaces, thereby hindering the binding of small chemical inhibitors, or even if binding occurs it is difficult to restrict interactions or functionalities on the large complex as a whole. ${ }^{78}$

\section{Future Perspectives}

Although challenges abound for the development of new antimitotics, optimization and potency improvement of existing drugs, it is still possible to exploit current drugs under new strategies. One cannot ignore the ubiquitous efficacy shown by these drugs in preclinical work. With more research to validate targets and to better understand the translational barrier in clinical application, targeting the mitotic defects of cancer cells can still be useful in anti-cancer therapy.

Granted the two main reasons behind failed mitosisselective approaches are the underestimated slowness of human tumor-doubling time and the occurrence of mitotic slippage, one can envisage two possible ways to circumvent the complications: (i) antagonizing cancer-specific target that has oncogenic roles outside mitosis (i.e., important throughout the cell-cycle), and (ii) combining targeted inhibitors to maximize mitotic arrest-cell death and minimize mitotic exit (combinatorial therapy).

There are many versatile proteins that have significant roles encompassing both interphase and mitosis, but it is extremely rare to identify one that is cancer specific. Survivin, which belongs to the Inhibitor of Apoptosis Protein (IAP) family, is one among the few. While Survivin is a vital suppressor of apoptosis, it is also an integral component of the chromosome passenger complex (CPC), which directs mitotic activities. ${ }^{79}$ The expression of Survivin is cell cycle-regulated and escalates to a maximum during the G2/M phase, consistent with its role in mitosis. Survivin strikes as a clear cancerspecific gene, as it is overexpressed in practically every human tumor examined. As a cell death regulator, Survivin exhibits its cytoprotectivity either directly or indirectly through the suppression of pro-apoptotic molecules such as the caspases. $^{80,81}$ We have reported that Survivin withdrawal via abrogated nucleocytoplasmic transport tilts the survival balance irreversibly to the execution of apoptosis. ${ }^{82,83}$ Other studies involving the physical or functional termination of Survivin by various molecular entities demonstrated spontaneous sensitization to caspase-dependent apoptosis in vitro and also in animal models. ${ }^{84,85}$ Conversely, as a mitotic 
facilitator, Survivin interacts with Borealin, INCENP, and Aurora-B to form the functional CPC. Downregulation and functional attenuation of Survivin revealed severe defects in mitotic spindles assembly and maintenance, compromised spindle checkpoint surveillance, aberrant chromosome movements, increase in ploidy and the inability to complete cytokinesis. $^{86,87}$ Taken together, a therapeutic targeting Survivin is likely to transcend the shortcomings of antimitotics. Several anti-Survivin strategies have been devised over the years to varied levels of success. Encouragingly, early-phase human trials of Survivin inhibitors showed tolerable toxicity and proofs of clinical efficacy. ${ }^{88}$

Pertaining to the high rates of mitotic slippages in cancer cells as a result of SAC-related mutations and the prevalent basal level of Cyclin B degradation, targeting mitotic exit has shown remarkable results thus far. Similarly, this approach can be extrapolated to aim at targets involved in different stages of mitosis, thus collectively achieving maximum MCD. It is interesting to speculate on the efficacy of combinatorial treatment involving simultaneous inhibitions of mitotic entry and/or spindle-associated/mitotic checkpoint targets together with mitotic exit. The idea is that it is unlikely for tumor cells to escape targeted interventions that hit them sequentially in waves at different stages of mitosis. In addition, such intense regimen would leave no room for acquired resistance to develop. Figure 2 depicts the network of selected druggable targets at various stages of mitosis, many of which shared regulatory connections, downstream targets and substrates. The possible numbers and permutations of antimitotic targets that can be selected are theoretically endless (limited only to the tolerance level of a patient); the challenge would then be to find combinations that work synergistically and complement one another.

Such tactic is not without ramifications, prompting careful considerations and comprehensive analysis in devising combinatorial strategies. In any antimitotic treatment, cytotoxicity is seen not only in cancer cells but also in healthy cycling cells, particularly the bone marrow myeloid progenitor

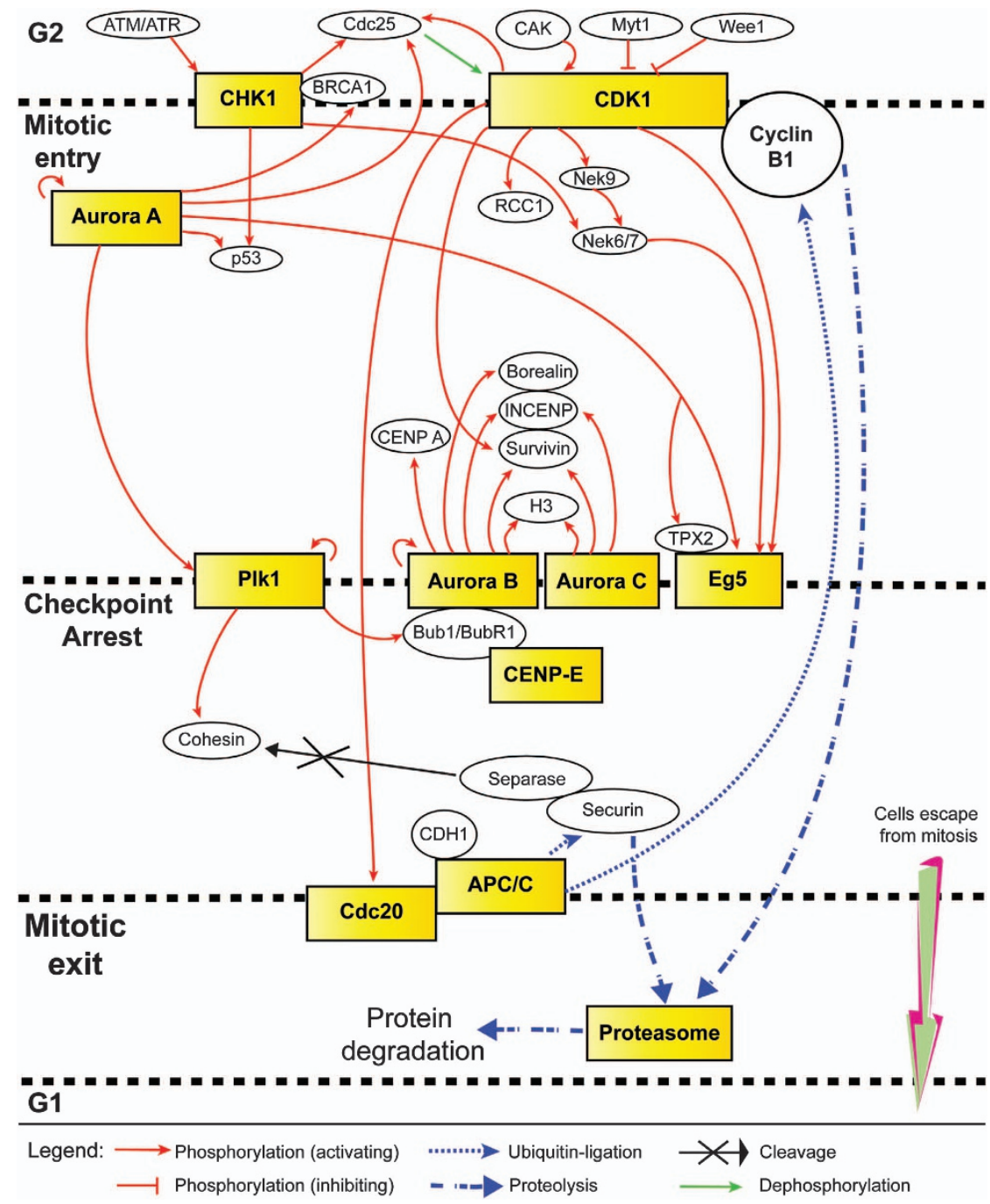

Figure 2 Interplay of pharmacologic targets in mitosis. A combinatorial anti-mitotic regimen encompassing inhibitors concurrently targeting different stages of mitosis (limiting mitotic entry, strengthening checkpoint arrest and preventing mitotic exit, all of which lead to cell death) may yield higher efficacy in terms of clinical treatment. In addition, such an intense strategy is likely to minimize the development of acquired resistance and/or reduce the drawback of response heterogeneity 
cells. In accordance, the fear is that multiple drugs targeting various levels of regulatory molecules might not achieve relevant clinical activity because of dosage limitations as set by bone marrow toxicity or alternative detrimental effects on other dividing tissues. Further questions can be asked regarding the duration of the strategy, the reversibility of side effects under persisted therapy and the cross-reactivity of the combined antimitotics. Regardless, considering the preliminary success of targeting mitotic exit, a multiphase combinatorial antimitotic strategy provides an alternative and interesting avenue towards developing more effective mitosis-selective therapies.

\section{Summary}

From the perspective of tumor cells, one key distinction that separates them from the non-dividing cells in the body is that they undergo unrestricted growth. Perhaps not in terms of proliferation rate (especially when compared to normal dividing cells), but for them to grow, they need to divide. This crudely covers the issue of selectivity to a certain extent and confers vulnerability during cellular division, thus making mitosis a valid point of intervention in anti-cancer therapy. It is widely regarded that antimitotics cause prolonged mitotic arrest due to the activation of SAC. Following mitotic arrest, the cells can die from MCD or adopt different cell fates. ${ }^{7} \mathrm{~A}$ repertoire of chemical inhibitors targeting various mitosisspecific kinases, motor proteins and multiprotein complexes has been developed since the relative success of the classical microtubule poisons. These drugs are naturally more mitosisselective yet without the side effect of neurotoxicities. However, dramatic bench results do not necessarily translate to bedside efficacy, as seen in a majority of these mitotic therapeutics. The inherent slow growth of human tumors and the rapid development of drug resistance (associated to mitotic slippages both as a cause and as a consequence) limit patients' response and curb the full potential of existing mitosis-selective inhibitors. As such, much work is needed to map out the complexities of how cytotoxic drugs work as medicine, to harness the full potential of antimitotics, and to resolve the gaps behind preclinical to clinical shortcomings. Identifying new cancer-specific druggable molecules, optimizing combinatorial treatments and devising novel anticancer strategies remain a future challenge and hope for treating cancer.

\section{Conflict of Interest}

The authors declare no conflict of interest.

Acknowledgements. This work was supported by the Academic Research Fund RG 17/11 (MOE, Singapore) and the Biomedical Research Council, Singapore.

\section{Author contributions}

All authors contributed to planning, researching and writing this review.

1. Kastan MB, Bartek J. Cell-cycle checkpoints and cancer. Nature 2004; 432: 316-323.

2. Rieder $\mathrm{CL}$, Maiato $\mathrm{H}$. Stuck in division or passing through: what happens when cells cannot satisfy the spindle assembly checkpoint. Dev Cell 2004; 7: 637-651.
3. Castedo M, Perfettini JL, Roumier T, Andreau K, Medema R, Kroemer G. Cell death by mitotic catastrophe: a molecular definition. Oncogene 2004; 23: 2825-2837.

4. Jonathan EC, Bernhard EJ, McKenna WG. How does radiation kill cells? Curr Opin Chem Biol 1999; 3: 77-83

5. Xi G, Hu X, Wu B, Jiang H, Young CY, Pang $Y$ et al. Autophagy inhibition promotes paclitaxel-induced apoptosis in cancer cells. Cancer Lett 2011; 307: 141-148.

6. Hadfield JA, Ducki S, Hirst N, McGown AT. Tubulin and microtubules as targets for anticancer drugs. Prog Cell Cycle Res 2003; 5: 309-325.

7. Weaver BA, Cleveland DW. Decoding the links between mitosis, cancer, and chemotherapy: The mitotic checkpoint, adaptation, and cell death. Cancer Cell 2005; 8: $7-12$.

8. Jordan MA, Wilson L. Microtubules as a target for anticancer drugs. Nat Rev Cancer 2004; 4: 253-265

9. Rowinsky EK, Donehower RC. Paclitaxel (taxol). New Engl J Med 1995; 332: 1004-1014.

10. Pinsky BA, Biggins S. The spindle checkpoint: tension versus attachment. Trends Cell Biol 2005; 15: 486-493.

11. Schmidt M, Bastians $\mathrm{H}$. Mitotic drug targets and the development of novel anti-mitotic anticancer drugs. Drug Resist Update 2007; 10: 162-181.

12. John PC, Mews M, Moore R. Cyclin/Cdk complexes: their involvement in cell cycle progression and mitotic division. Protoplasma 2001; 216: 119-142.

13. Nigg EA. Mitotic kinases as regulators of cell division and its checkpoints. Nat Rev Mol Cell Biol 2001; 2: 21-32.

14. Shapiro Gl. Cyclin-dependent kinase pathways as targets for cancer treatment. J Clin Oncol 2006; 24: 1770-1783.

15. Niida H, Nakanishi M. DNA damage checkpoints in mammals. Mutagenesis 2006; 21: 3-9.

16. Anderson HJ, Andersen RJ, Roberge M. Inhibitors of the G2 DNA damage checkpoint and their potential for cancer therapy. Prog Cell Cycle Res 2003; 5: 423-430.

17. Chan TA, Hermeking H, Lengauer C, Kinzler KW, Vogelstein B. 14-3-3Sigma is required to prevent mitotic catastrophe after DNA damage. Nature 1999; 401: 616-620.

18. Jackson JR, Patrick DR, Dar MM, Huang PS. Targeted anti-mitotic therapies: can we improve on tubulin agents? Nat Rev Cancer 2007; 7: 107-117.

19. Brown JR, Koretke KK, Birkeland ML, Sanseau P, Patrick DR. Evolutionary relationships of Aurora kinases: implications for model organism studies and the development of anticancer drugs. BMC Evol Biol 2004; 4: 39.

20. Strebhardt K, Ullrich A. Targeting polo-like kinase 1 for cancer therapy. Nat Rev Cancer 2006; 6: 321-330

21. Barr FA, Sillje HH, Nigg EA. Polo-like kinases and the orchestration of cell division. Nat Rev Mol Cell Biol 2004; 5: 429-440.

22. Carmena M, Earnshaw WC. The cellular geography of aurora kinases. Nat Rev Mol Cell Biol 2003; 4: 842-854

23. Lens SM, Voest EE, Medema RH. Shared and separate functions of polo-like kinases and aurora kinases in cancer. Nat Rev Cancer 2010; 10: 825-841.

24. Girdler F, Gascoigne KE, Eyers PA, Hartmuth S, Crafter C, Foote KM et al. Validating Aurora B as an anti-cancer drug target. J Cell Sci 2006; 119: 3664-3675.

25. Kelly $A E$, Funabiki $H$. Correcting aberrant kinetochore microtubule attachments: an Aurora B-centric view. Curr Opin Cell Biol 2009; 21: 51-58

26. Mayer TU, Kapoor TM, Haggarty SJ, King RW, Schreiber SL, Mitchison TJ. Small molecule inhibitor of mitotic spindle bipolarity identified in a phenotype-based screen. Science 1999; 286: 971-974.

27. Kapoor TM, Mayer TU, Coughlin ML, Mitchison TJ. Probing spindle assembly mechanisms with monastrol, a small molecule inhibitor of the mitotic kinesin, Eg5. J Cell Biol 2000; 150: 975-988.

28. Marcus Al, Peters U, Thomas SL, Garrett S, Zelnak A, Kapoor TM et al. Mitotic kinesin inhibitors induce mitotic arrest and cell death in Taxol-resistant and -sensitive cancer cells. J Biol Chem 2005; 280: 11569-11577.

29. Huszar D, Theoclitou ME, Skolnik J, Herbst R. Kinesin motor proteins as targets for cancer therapy. Cancer Metastasis Rev 2009; 28: 197-208.

30. Wood KW, Sakowicz R, Goldstein LS, Cleveland DW. CENP-E is a plus end-directed kinetochore motor required for metaphase chromosome alignment. Cell 1997; 91: 357-366

31. Yao X, Abrieu A, Zheng Y, Sullivan KF, Cleveland DW. CENP-E forms a link between attachment of spindle microtubules to kinetochores and the mitotic checkpoint. Nat Cell Biol 2000; 2: 484-491.

32. Wood KW, Lad L, Luo L, Qian X, Knight SD, Nevins N et al. Antitumor activity of an allosteric inhibitor of centromere-associated protein-E. Proc Natl Acad Sci USA 107 5839-5844.

33. Schafer-Hales K, laconelli J, Snyder JP, Prussia A, Nettles JH, El-Naggar A et al. Farnesyl transferase inhibitors impair chromosomal maintenance in cell lines and human tumors by compromising CENP-E and CENP-F function. Mol Cancer Ther 2007; 6: $1317-1328$

34. Weaver BA, Silk AD, Montagna C, Verdier-Pinard P, Cleveland DW. Aneuploidy acts both oncogenically and as a tumor suppressor. Cancer Cell 2007; 11: 25-36.

35. Chung V, Heath El, Schelman WR, Johnson BM, Kirby LC, Lynch KM et al. First-time-inhuman study of GSK923295, a novel antimitotic inhibitor of centromere-associated protein $\mathrm{E}$ (CENP-E), in patients with refractory cancer. Cancer Chemother Pharmacol 69: 733-741. 
36. Thornton BR, Toczyski DP. Securin and B-cyclin/CDK are the only essential targets of the APC. Nat Cell Biol 2003; 5: 1090-1094.

37. Smolders $\mathrm{L}$, Teodoro JG. Targeting the anaphase promoting complex: common pathways for viral infection and cancer therapy. Expert Opin Ther Targets 15: 767-780.

38. Gascoigne KE, Taylor SS. Cancer cells display profound intra- and interline variation following prolonged exposure to antimitotic drugs. Cancer Cell 2008; 14: 111-122.

39. Huang HC, Shi J, Orth JD, Mitchison TJ. Evidence that mitotic exit is a better cancer therapeutic target than spindle assembly. Cancer Cell 2009; 16: 347-358.

40. Manchado E, Guillamot M, de Carcer G, Eguren M, Trickey M, Garcia-Higuera I et al. Targeting mitotic exit leads to tumor regression in vivo: modulation by Cdk1, Mastl, and the PP2A/B55alpha,delta phosphatase. Cancer Cell 2010; 18: 641-654.

41. Zeng X, Sigoillot F, Gaur S, Choi S, Pfaff KL, Oh DC et al. Pharmacologic inhibition of the anaphase-promoting complex induces a spindle checkpoint-dependent mitotic arrest in the absence of spindle damage. Cancer Cell 2010; 18: 382-395.

42. Ciechanover A, Schwartz AL. The ubiquitin system: pathogenesis of human diseases and drug targeting. BBA-Mol Cell Res 2004; 1695: 3-17.

43. Einsele H. Bortezomib. Recent Results Cancer Res 2010; 184: 173-187.

44. Shen L, Au WY, Wong KY, Shimizu N, Tsuchiyama J, Kwong YL et al. Cell death by bortezomib-induced mitotic catastrophe in natural killer lymphoma cells. Mol Cancer Ther 2008; 7: 3807-3815.

45. Bae SH, Ryoo HM, Kim MK, Lee KH, Sin Jl, Hyun MS. Effects of the proteasome inhibitor bortezomib alone and in combination with chemotherapeutic agents in gastric cancer cell lines. Oncol Rep 2008; 19: 1027-1032.

46. Wagenblast J, Hambek M, Baghi M, Gstottner W, Strebhardt K, Ackermann $\mathrm{H}$ et al. Antiproliferative activity of bortezomib alone and in combination with cisplatin or docetaxel in head and neck squamous cell carcinoma cell lines. J Cancer Res Clin Oncol 2008; 134: 323-330.

47. Cresta S, Sessa C, Catapano CV, Gallerani E, Passalacqua D, Rinaldi A et al. Phase I study of bortezomib with weekly paclitaxel in patients with advanced solid tumors. Eur J Cancer 2008; 44: 1829-1834.

48. Croghan GA, Suman VJ, Maples WJ, Albertini M, Linette G, Flaherty L et al. A study of paclitaxel, carboplatin, and bortezomib in the treatment of metastatic malignant melanoma: a phase 2 consortium study. Cancer 2010; 116: 3463-3468.

49. Craig RW. MCL1 provides a window on the role of the BCL2 family in cell proliferation, differentiation and tumorigenesis. Leukemia 2002; 16: 444-454.

50. Wertz IE, Kusam S, Lam C, Okamoto T, Sandoval W, Anderson DJ et al. Sensitivity to antitubulin chemotherapeutics is regulated by MCL1 and FBW7. Nature 2011; 471: 110-114.

51. Kaufmann SH, Karp JE, Svingen PA, Krajewski S, Burke PJ, Gore SD et al. Elevated expression of the apoptotic regulator Mcl-1 at the time of leukemic relapse. Blood 1998; 91: $991-1000$.

52. Khoury JD, Medeiros LJ, Rassidakis GZ, McDonnell TJ, Abruzzo LV, Lai R. Expression of Mcl-1 in mantle cell lymphoma is associated with high-grade morphology, a high proliferative state, and p53 overexpression. J Pathol 2003; 199: 90-97.

53. Matson DR, Stukenberg PT. Spindle poisons and cell fate: a tale of two pathways. Mol Interv 2011; 11: 141-150.

54. Dalton WB, Nandan MO, Moore RT, Yang VW. Human cancer cells commonly acquire DNA damage during mitotic arrest. Cancer Res 2007; 67: 11487-11492.

55. Lai SK, Wong CH, Lee YP, Li HY. Caspase-3-mediated degradation of condensin Cap-H regulates mitotic cell death. Cell Death Differ 2011; 18: 996-1004.

56. Ono T, Fang Y, Spector DL, Hirano T. Spatial and temporal regulation of Condensins I and II in mitotic chromosome assembly in human cells. Mol Biol Cell 2004; 15: 3296-3308.

57. Zhai L, Wang H, Tang W, Liu W, Hao S, Zeng X. Disturbance in function and expression of condensin affects chromosome compaction in HeLa cells. Cell Biol Int 2011; 35: 735-740.

58. Komlodi-Pasztor E, Sackett DL, Fojo AT. Inhibitors targeting mitosis: tales of how great drugs against a promising target were brought down by a flawed rationale. Clin Cancer Res 2012; 18: 51-63.

59. Steegmaier M, Hoffmann M, Baum A, Lenart P, Petronczki M, Krssak M et al. BI 2536, a potent and selective inhibitor of polo-like kinase 1, inhibits tumor growth in vivo. Curr Biol 2007; 17: 316-322.

60. Amadori D, Volpi A, Maltoni R, Nanni O, Amaducci L, Amadori A et al. Cell proliferation as a predictor of response to chemotherapy in metastatic breast cancer: a prospective study. Breast Cancer Res Treat 1997; 43: 7-14.

61. Szende B, Romics I, Minik K, Szabo J, Torda I, Lovasz S et al. Repeated biopsies in evaluation of therapeutic effects in prostate carcinoma. Prostate 2001; 49: 93-100.

62. Weidner N, Moore DH 2nd, Vartanian R. Correlation of Ki-67 antigen expression with mitotic figure index and tumor grade in breast carcinomas using the novel "paraffin"reactive MIB1 antibody. Hum Pathol 1994; 25: 337-342.

63. Mitchison TJ. The proliferation rate paradox in antimitotic chemotherapy. Mol Biol Cell 2012; 23: 1-6.

64. Olmos D, Barker D, Sharma R, Brunetto AT, Yap TA, Taegtmeyer AB et al. Phase I study of GSK461364, a specific and competitive Polo-like kinase 1 inhibitor, in patients with advanced solid malignancies. Clin Cancer Res 2011; 17: 3420-3430.

65. Souid AK, Dubowy RL, Ingle AM, Conlan MG, Sun J, Blaney SM et al. A pediatric phase I trial and pharmacokinetic study of ispinesib: a Children's Oncology Group phase I consortium study. Pediatr Blood Cancer 2010; 55: 1323-1328.
66. Mori T, Kinoshita Y, Watanabe A, Yamaguchi T, Hosokawa K, Honjo H. Retention of paclitaxel in cancer cells for 1 week in vivo and in vitro. Cancer Chemother Pharmacol 2006; 58: 665-672.

67. Longley DB, Johnston PG. Molecular mechanisms of drug resistance. J Pathol 2005; 205: 275-292.

68. Kavallaris M. Microtubules and resistance to tubulin-binding agents. Nat Rev Cancer 2010; 10: 194-204

69. Tcherniuk S, van Lis R, Kozielski F, Skoufias DA. Mutations in the human kinesin Eg5 that confer resistance to monastrol and S-trityl-L-cysteine in tumor derived cell lines. Biochem Pharmacol 2010; 79: 864-872.

70. Kuukasjarvi T, Karhu R, Tanner M, Kahkonen M, Schaffer A, Nupponen N et al. Genetic heterogeneity and clonal evolution underlying development of asynchronous metastasis in human breast cancer. Cancer Res 1997; 57: 1597-1604.

71. McClelland SE, Burrell RA, Swanton C. Chromosomal instability: a composite phenotype that influences sensitivity to chemotherapy. Cell Cycle 2009; 8: 3262-3266.

72. Kops GJ, Foltz DR, Cleveland DW. Lethality to human cancer cells through massive chromosome loss by inhibition of the mitotic checkpoint. Proc Natl Acad Sci USA 2004; 101: 8699-8704.

73. Colombo R, Caldarelli M, Mennecozzi M, Giorgini ML, Sola F, Cappella P et al. Targeting the mitotic checkpoint for cancer therapy with NMS-P715, an inhibitor of MPS1 kinase. Cancer Res 2010; 70: 10255-10264.

74. Janssen A, Kops GJ, Medema RH. Elevating the frequency of chromosome mis-segregation as a strategy to kill tumor cells. Proc Natl Acad Sci USA 2009; 106 19108-19113.

75. Mazzorana M, Montoya G, Mortuza GB. The centrosome: a target for cancer therapy Curr Cancer Drug Targets 2011; 11: 600-612.

76. Smith $\mathrm{P}$, Syed N, Crook T. Epigenetic inactivation implies a tumor suppressor function in hematologic malignancies for Polo-like kinase 2 but not Polo-like kinase 3. Cell Cycle 2006; 5: 1262-1264.

77. Ko MA, Rosario CO, Hudson JW, Kulkarni S, Pollett A, Dennis JW et al. Plk4 haploinsufficiency causes mitotic infidelity and carcinogenesis. Nat Genet 2005; 37 883-888.

78. Blundell TL, Sibanda BL, Montalvao RW, Brewerton S, Chelliah V, Worth CL et al. Structural biology and bioinformatics in drug design: opportunities and challenges for target identification and lead discovery. Philos Trans R Soc Lond B Biol Sci 2006; 361: 413-423.

79. Lens SM, Vader G, Medema RH. The case for Survivin as mitotic regulator. Curr Opin Cell Biol 2006; 18: 616-622.

80. Dohi T, Okada K, Xia F, Wilford CE, Samuel T, Welsh K et al. An IAP-IAP complex inhibits apoptosis. J Biol Chem 2004; 279: 34087-34090.

81. Dohi T, Xia F, Altieri DC. Compartmentalized phosphorylation of IAP by protein kinase A regulates cytoprotection. Mol Cell 2007; 27: 17-28.

82. Chan KS, Wong $\mathrm{CH}$, Huang YF, Li HY. Survivin withdrawal by nuclear export failure as a physiological switch to commit cells to apoptosis. Cell Death Dis 2010; 1: e57.

83. Wong $\mathrm{CH}, \mathrm{Chan} \mathrm{H}, \mathrm{Ho}$ CY, Lai SK, Chan KS, Koh CG et al. Apoptotic histone modification inhibits nuclear transport by regulating RCC1. Nat Cell Biol 2009; 11: 36-45.

84. Olie RA, Simoes-Wust AP, Baumann B, Leech SH, Fabbro D, Stahel RA et al. A novel antisense oligonucleotide targeting survivin expression induces apoptosis and sensitizes lung cancer cells to chemotherapy. Cancer Res 2000; 60: 2805-2809.

85. Shankar SL, Mani S, O'Guin KN, Kandimalla ER, Agrawal S, Shafit-Zagardo B. Survivin inhibition induces human neural tumor cell death through caspase-independent anddependent pathways. J Neurochem 2001; 79: 426-436.

86. Honda R, Korner R, Nigg EA. Exploring the functional interactions between Aurora B, INCENP, and survivin in mitosis. Mol Biol Cell 2003; 14: 3325-3341.

87. Li F, Ackermann EJ, Bennett CF, Rothermel AL, Plescia J, Tognin S et al. Pleiotropic celldivision defects and apoptosis induced by interference with survivin function. Nat Cell Biol 1999; 1: 461-466.

88. Church DN, Talbot DC. Survivin in solid tumors: rationale for development of inhibitors. Curr Oncol Rep 2012; 14: 120-128.

89. Ferrandina G, Mariani M, Andreoli M, Shahabi S, Scambia G, Ferlini C. Novel drugs targeting microtubules: the role of epothilones. Curr Pharm Design 2012; 18: 2793-2803.

90. Tse AN, Rendahl KG, Sheikh T, Cheema H, Aardalen K, Embry M et al. CHIR-124, a novel potent inhibitor of Chk1, potentiates the cytotoxicity of topoisomerase I poisons in vitro and in vivo. Clin Cancer Res 2007; 13: 591-602.

91. Syljuasen RG, Sorensen CS, Nylandsted J, Lukas C, Lukas J, Bartek J. Inhibition of Chk1 by CEP-3891 accelerates mitotic nuclear fragmentation in response to ionizing radiation. Cancer Res 2004; 64: 9035-9040.

92. Matthews DJ, Yakes FM, Chen J, Tadano M, Bornheim L, Clary DO et al. Pharmacological abrogation of S-phase checkpoint enhances the anti-tumor activity of gemcitabine in vivo. Cell Cycle 2007; 6: 104-110.

93. Gartner EM, Silverman P, Simon M, Flaherty L, Abrams J, Ivy P et al. A phase II study of 17-allylamino-17-demethoxygeldanamycin in metastatic or locally advanced, unresectable breast cancer. Breast Cancer Res Treat 2012; 131: 933-937.

94. Hendrickson AE, Oberg AL, Glaser G, Camoriano JK, Peethambaram PP, ColonOtero $\mathrm{G}$ et al. A phase II study of gemcitabine in combination with tanespimycin in 
advanced epithelial ovarian and primary peritoneal carcinoma. Gynecol Oncol 2012; 124 210-215.

95. Jackman KM, Frye CB, Hunger SP. Flavopiridol displays preclinical activity in acute lymphoblastic leukemia. Pediatr Blood Cancer 2008; 50: 772-778.

96. Li Y, Tanaka K, Li X, Okada T, Nakamura T, Takasaki M et al. Cyclin-dependent kinase inhibitor, flavopiridol, induces apoptosis and inhibits tumor growth in drug-resistan osteosarcoma and Ewing's family tumor cells. Int J Cancer 2007; 121: 1212-1218.

97. Smith ME, Cimica V, Chinni S, Challagulla K, Mani S, Kalpana GV. Rhabdoid tumor growth is inhibited by flavopiridol. Clin Cancer Res 2008; 14: 523-532.

98. Kummar S, Gutierrez ME, Gardner ER, Figg WD, Melillo G, Dancey J et al. A phase I trial of UCN-01 and prednisone in patients with refractory solid tumors and lymphomas. Cancer Chemother Pharmacol 2010; 65: 383-389.

99. Li T, Christensen SD, Frankel PH, Margolin KA, Agarwala SS, Luu T et al. A phase II study of cell cycle inhibitor UCN-01 in patients with metastatic melanoma: a California Cancer Consortium trial. Invest New Drugs 30: 741-748.

100. Lin JP, Yang JS, Lee JH, Hsieh WT, Chung JG. Berberine induces cell cycle arrest and apoptosis in human gastric carcinoma SNU-5 cell line. World J Gastroenterol 2006; 12 21-28.

101. Choi EJ, Kim GH. Daidzein causes cell cycle arrest at the G1 and G2/M phases in human breast cancer MCF-7 and MDA-MB-453 cells. Phytomedicine 2008; 15: 683-690.

102. Joshi KS, Rathos MJ, Mahajan P, Wagh V, Shenoy S, Bhatia D et al. P276-00, a novel cyclin-dependent inhibitor induces G1-G2 arrest, shows antitumor activity on cisplatinresistant cells and significant in vivo efficacy in tumor models. Mol Cancer Ther 2007; 6 : 926-934.

103. Raje N, Hideshima T, Mukherjee S, Raab M, Vallet S, Chhetri S et al. Preclinical activity of P276-00, a novel small-molecule cyclin-dependent kinase inhibitor in the therapy of multiple myeloma. Leukemia 2009; 23: 961-970.

104. Wang Y, Ji P, Liu J, Broaddus RR, Xue F, Zhang W. Centrosome-associated regulators of the $\mathrm{G}(2) / \mathrm{M}$ checkpoint as targets for cancer therapy. Mol Cancer 2009; 8: 8 .

105. Walsby E, Walsh V, Pepper C, Burnett A, Mills K. Effects of the aurora kinase inhibitors AZD1152-HQPA and ZM447439 on growth arrest and polyploidy in acute myeloid leukemia cell lines and primary blasts. Haematologica 2008; 93: 662-669.

106. Soncini C, Carpinelli P, Gianellini L, Fancelli D, Vianello P, Rusconi L et al. PHA-680632, a novel Aurora kinase inhibitor with potent antitumoral activity. Clin Cancer Res 2006; 12 4080-4089

107. Ellis $\mathrm{PM}$, Chu QS, Leighl N, Laurie SA, Fritsch $\mathrm{H}$, Gaschler-Markefski B et al. A phase i open-label dose-escalation study of intravenous bi 2536 together with Pemetrexed in previously treated patients with non-small-cell lung cancer. Clin Lung Cancer 2012; e-pub ahead of print 31 May 2012; doi:10.1016/j.cllc.2012.04.003.

108. Mross K, Dittrich C, Aulitzky WE, Strumberg D, Schutte J, Schmid RM et al. A randomised phase II trial of the Polo-like kinase inhibitor $\mathrm{BI} 2536$ in chemo-naive patients with unresectable exocrine adenocarcinoma of the pancreas-a study within the Centra European Society Anticancer Drug Research (CESAR) collaborative network. $\mathrm{Br} J$ Cancer 2012; 107: 280-286.

109. Jimeno A, Li J, Messersmith WA, Laheru D, Rudek MA, Maniar M et al. Phase I study of ON 01910.Na, a novel modulator of the Polo-like kinase 1 pathway, in adult patients with solid tumors. J Clin Oncol 2008; 26: 5504-5510.

110. Schoffski $P$, Awada A, Dumez H, Gil T, Bartholomeus S, Wolter P et al. A phase I, doseescalation study of the novel Polo-like kinase inhibitor volasertib (BI 6727) in patients with advanced solid tumours. Eur J Cancer 2012; 48: 179-186.

111. Hikichi Y, Honda K, Hikami K, Miyashita H, Kaieda I, Murai S et al. TAK-960, a novel, orally available, selective inhibitor of polo-like kinase 1 , shows broad-spectrum preclinical antitumor activity in multiple dosing regimens. Mol Cancer Ther 2012; 11: 700-709.

112. Gomez HL, Philco M, Pimentel P, Kiyan M, Monsalvo ML, Conlan MG et al. Phase I doseescalation and pharmacokinetic study of ispinesib, a kinesin spindle protein inhibitor, administered on days 1 and 15 of a 28-day schedule in patients with no prior treatment for advanced breast cancer. Anticancer Drugs 2011; 23: 335-341.

113. Burris HA 3rd, Jones SF, Williams DD, Kathman SJ, Hodge JP, Pandite L et al. A phase study of ispinesib, a kinesin spindle protein inhibitor, administered weekly for three consecutive weeks of a 28-day cycle in patients with solid tumors. Invest New Drugs 2011; 29: 467-472.

114. Infante JR, Kurzrock R, Spratlin J, Burris HA, Eckhardt SG, Li J et al. A Phase I study to assess the safety, tolerability, and pharmacokinetics of AZD4877, an intravenous Eg5 inhibitor in patients with advanced solid tumors. Cancer Chemoth Pharm 2012; 69: 165-172.

115. Theoclitou ME, Aquila B, Block MH, Brassil PJ, Castriotta L, Code E et al. Discovery of $(+)$-N-(3-aminopropyl)-N-[1-(5-benzyl-3-methyl-4-oxo-[1,2]thiazolo[5,4-d]pyrimidin -6-yl)-2-methylpropyl]-4-methylbenzamide (AZD4877), a kinesin spindle protein inhibitor and potential anticancer agent. J Med Chem 2011; 54: 6734-6750.

116. Chauhan D, Singh AV, Aujay M, Kirk CJ, Bandi M, Ciccarelli B et al. A novel orally active proteasome inhibitor ONX 0912 triggers in vitro and in vivo cytotoxicity in multiple myeloma. Blood 2010; 116: 4906-4915
117. Mato AR, Feldman T, Goy A. Proteasome inhibition and combination therapy for NonHodgkin's lymphoma: from bench to bedside. Oncologist 2012; 17: 694-707.

118. Benga G. Basic studies on gene therapy of human malignant melanoma by use of the human interferon beta gene entrapped in cationic multilamellar liposomes. 1. Morphology and growth rate of six melanoma cell lines used in transfection experiments with the human interferon beta gene. J Cell Mol Med 2001; 5: 402-408.

119. Cendan JC, Souba WW, Copeland EM 3rd, Lind DS. Increased L-arginine transport in a nitric oxide-producing metastatic colon cancer cell line. Ann Surg Oncol 1996; 3: 501-508.

120. Gonzalez-Moreno O, Calvo A, Joshi BH, Abasolo I, Leland P, Wang Z et al. Gene expression profiling identifies IL-13 receptor alpha 2 chain as a therapeutic target in prostate tumor cells overexpressing adrenomedullin. Int J Cancer 2005; 114: 870-878.

121. Hayostek CJ, Koval TM. Radiosensitization of human tumor cells with levamisole. Cance Res 1992; 52: 3228-3230.

122. Kim EH, Lee HJ, Lee DH, Bae S, Soh JW, Jeoung D et al. Inhibition of heat shock protein 27-mediated resistance to DNA damaging agents by a novel PKC delta-V 5 heptapeptide. Cancer Res 2007; 67: 6333-6341.

123. Ku JL, Kim KH, Choi JS, Jeon YK, Kim SH, Shin YK et al. Establishment and characterization of six human lung cancer cell lines: EGFR, p53 gene mutations and expressions of drug sensitivity genes. Cell Oncol 2011; 34: 45-54.

124. Li G, Nelsen C, Hendrickson EA. Ku86 is essential in human somatic cells. Proc Natl Acad Sci USA 2002; 99: 832-837.

125. Lin MF, Meng TC, Rao PS, Chang C, Schonthal AH, Lin FF. Expression of human prostatic acid phosphatase correlates with androgen-stimulated cell proliferation in prostate cancer cell lines. J Biol Chem 1998; 273: 5939-5947.

126. Sharma M, Dube A, Bansal H, Kumar Gupta P. Effect of pH on uptake and photodynamic action of chlorin $\mathrm{p} 6$ on human colon and breast adenocarcinoma cell lines. Photochem Photobiol Sci 2004; 3: 231-235.

127. Watanabe N, Okochi E, Mochizuki M, Sugimura T, Ushijima T. The presence of single nucleotide instability in human breast cancer cell lines. Cancer Res 2001; 61: 7739-7742.

128. Suzuki M, Sunaga N, Shames DS, Toyooka S, Gazdar AF, Minna JD. RNA interferencemediated knockdown of DNA methyltransferase 1 leads to promoter demethylation and gene re-expression in human lung and breast cancer cells. Cancer Res 2004; 64: 3137-3143.

129. Mohammad RM, Mohamed AN, Hamdan MY, Vo T, Chen B, Katato $\mathrm{K}$ et al. Establishment of a human B-CLL xenograft model: utility as a preclinical therapeutic model. Leukemia 1996; 10: 130-137.

130. Stacchini A, Aragno M, Vallario A, Alfarano A, Circosta P, Gottardi D et al. MEC1 and MEC2: two new cell lines derived from B-chronic lymphocytic leukaemia in prolymphocytoid transformation. Leuk Res 1999; 23: 127-136.

131. Molica S, Alberti A. Prognostic value of the lymphocyte doubling time in chronic lymphocytic leukemia. Cancer 1987; 60: 2712-2716.

132. Koeffler HP, Golde DW. Human myeloid leukemia cell lines: a review. Blood 1980; 56: 344-350.

133. Hagenbeek A, Martens AC. Detection of minimal residual disease in acute leukemia: possibilities and limitations. Eur J Cancer Clin Oncol 1985; 21: 389-395.

134. Raza A, Preisler HD, Day R, Yasin Z, White M, Lykins J et al. Direct relationship between remission duration in acute myeloid leukemia and cell cycle kinetics: a leukemia intergroup study. Blood 1990; 76: 2191-2197.

135. Michor F, Hughes TP, Iwasa Y, Branford S, Shah NP, Sawyers CL et al. Dynamics of chronic myeloid leukaemia. Nature 2005; 435: 1267-1270.

136. Trere D, Pession A, Basso G, Rondelli R, Masera G, Paolucci G et al. Prognostic relevance of pretreatment proliferative rapidity of marrow blast cells in childhood acute lymphoblastic leukaemia. Br J Cancer 1994; 70: 1198-1202.

137. Milone MC, Fish JD, Carpenito C, Carroll RG, Binder GK, Teachey D et al. Chimeric receptors containing CD137 signal transduction domains mediate enhanced survival of $T$ cells and increased antileukemic efficacy in vivo. Mol Ther 2009; 17: 1453-1464.

138. Okabe S, Tauchi T, Ohyashiki K. Establishment of a new Philadelphia chromosomepositive acute lymphoblastic leukemia cell line (SK-9) with T315I mutation. Exp Hematol 2010; 38: 765-772.

139. Eisterer W, Jiang X, Christ O, Glimm H, Lee KH, Pang E et al. Different subsets of primary chronic myeloid leukemia stem cells engraft immunodeficient mice and produce a model of the human disease. Leukemia 2005; 19: 435-441.

Cell Death and Disease is an open-access journal published by Nature Publishing Group. This work is licensed under the Creative Commons Attribution-NonCommercial-No Derivative Works 3.0 Unported License. To view a copy of this license, visit http://creativecommons.org/licenses/by-nc-nd/3.0/ 